\title{
REWOLUCJA URBANISTYCZNA NA TERENIE ÎLE DE LA CITÉ W PARYŻU W XIX W. - PRZYCZYNY I SKUTKI
}

\author{
Abstract \\ URBAN REVOLUTION OF PARIS'S ÎLE DE LA CITÉ \\ IN THE $19^{\mathrm{TH}}$ CENTURY - REASONS AND CONSEQUENCES
}

Urban changes in Paris taking place in the time of the second Empire were generally viewed as positive. First of all, they solved the problem of old, non-hygienic, overpopulated, and dirty districts of the city and enabled the police to control the area in case of revolutionary movements. Moreover, they created the possibility of placing central, most important offices in prestigious locations, which added authority and splendor to them. As a result, the center of Paris became hygienic, utilitarian, safe and representative. However, these positive aspects of urban changes introduced under Napoleon III soon received severe criticism. The location of the Cité and the island on which it was located proved to be a curse for its urban development. Seeking to squeeze as many monumental governmental objects as possible on a small area resulted in almost complete destruction of the mediaeval urban structure of the district. The urban revolution which changed the Cité became a dramatic symbol of the authoritarian power of the Second Empire.

Key words: Paris, Île de la Cité, $19^{\text {th }}$ century, urban changes, Napoleon III, Georges Eugène Haussmann

Słowa kluczowe: Paryż, Île de la Cité, XIX wiek, urbanistyka, Napoleon III, Georges Eugène Haussmann

Obecny układ urbanistyczny Île de la Cité stworzono w drugiej połowie XIX stulecia za panowania Napoleona III. Usunięto wówczas niemal całkowicie średniowieczną zabudowę wyspy na Sekwanie (il. 1). Wyjątek uczyniono jedynie dla katedry Notre Dame, dawnego pałacu królewskiego z Sainte-Chapelle, części dzielnicy kanoników (Cloître Notre-Dame) 
oraz zabudowań na Place Dauphine ${ }^{1}$. Tak radykalna metamorfoza urbanistyczna Île de la Cité (il. 2) pociąga za sobą szereg pytań o jej przyczyny. Należy rozważyć, jak argumentowano potrzebę zmian, jakie były cele nowej zabudowy oraz jej ideowa wymowa. Dlaczego, w ramach zmian w tkance miejskiej w Paryżu, wobec Cité postąpiono najbardziej drastycznie, dokonując swoistej rewolucji urbanistycznej? Jak było oceniane całkowite przeobrażenie oblicza wyspy oraz zmiany jej funkcji i charakteru? Pytania te wytyczą kierunek rozważań, których celem jest wypełnienie luki w obecnym stanie badań nad historią île de la Cité.

\section{Preludium przemian}

Dawna zabudowa serca Paryża - wyspy na Sekwanie - pozostawała w niemal niezmiennym stanie do XVIII w. (il. 1). Choć w okresie oświecenia pojawiły się propozycje przebudowy urbanistycznej Île de la Cité, jednak pozostały one tylko na papierze², a wprowadzone zmiany polegały głównie na usunięciu kościołów: św. Marcjala (1722), św. Genowefy i św. Krzysztofa (1747), św. Jana, czyli dawnego baptysterium (1748), św. Michała przy Pałacu (1781-1782), św. Marii Magdaleny (1794)³ św. Symforiusza (1796) oraz św. Krzyża $(1797)^{4}$. Ingerencje te były wyraźnie widoczne, ponieważ budowle sakralne należały do tych elementów miejskiej tkanki, które górowały nad niskimi, mniej efektownymi i powtarzalnymi domami mieszkalnymi. Ten kierunek przemian, związany z desakralizacją miasta, został wzmocniony ideologicznie przez rewolucję francuską. Po burzliwych wydarzeniach ostatniego dziesięciolecia XVIII w. na wyspie zintensyfikowano proces wyburzania świątyń. Rozebrano wówczas następujące kościoły: Saint-Pierre-des-Arcis (1800)5 św. Germana $(1802)^{6}$, św. Agnieszki przy Petit-Pont $(1802-1803)^{7}$, Saint-Denis-de-la-Chartre

$1 \quad$ Plac założony w 1607 r. przez Henryka IV został uszczuplony jedynie przez wyburzenie w 1874 r. zabudowania przy rue Harlay: T. Hall, Planning Europe's Capital Cities. Aspects of Nineteenth-Century Urban Development, London 1997, s. 64.

2 Więcej na ten temat: Y. Ca rb on ni er, L'île de la Cité au XVIIIe siècle. Rénovation urbaine et adaptations habiles, [w:] Histoire de Paris. De l'áge classique à la modernité (XVIIe-XVIIIe siècle), red. Th. B ell e gu ic, L. Tu r cot, t. 1, Paris, 2013, s. 359-366; B. Hryszko, Od sacrum do profanum. Desakralizacja Île de la Cité w Paryżu w XVIII i XIX wieku, [w:] Sacrum w mieście: wymiar kulturowy, religijny i spoteczny, t. 2: Epoka nowożytna i czasy wspótczesne, red. D. Qu i r i n i - Po pław sk a, Ł. B u rki ewicz, Kraków 2016, s. 138-141.

3 Rok po sprzedaży został wyburzony. B. Dumouchel, L'église Sainte-Marie-Madeleine ou La Madeleine-en-la-Cité (1182-1794), „Bulletin de la Société de l'histoire de Paris et de l'Île-de-France” 1988 [1989], nr 115, s. 21-45.

4 J. Hilla i re t, L' ̂́le de la Cité, Paris 1969, s. 150.

5 Ibidem.

6 B. Du mou chel, L'église Saint-Germain-le-Vieux, „Bulletin de la Société de l'histoire de Paris et de l'Îlede-France" 1990 [1992], nr 117, s. 42.

7 M. Fosseyeux, L'Hôtel-Dieu de Paris au XVII'e et XVIII' siècle, Paris 1912, s. 246. 
$(1808)^{8}$, Saint-Denis-du-Pas $(1813-1814)^{9}$, św. Landeryka $(1829)^{10}$, a także Saint-Pierre -aux-Bœufs $(1837)^{11}$. Do zauważalnych zmian urbanistycznych z pierwszej połowy XIX w. należało również utworzenie w 1809 r. obecnego targu kwiatów i ptaków (Marché aux Fleurs et Oiseaux $)^{12}$ oraz wzniesienie w 1831 r. zakrystii według projektu Eugène’a Emmanuela Viollet-le-Duca na miejscu zburzonego pałacu arcybiskupiego.

\section{Przyczyny przemian w drugiej połowie XIX w.}

Radykalne zmiany na wyspie w okresie Drugiego Cesarstwa były częścią ambitnego planu Napoleona III, który pragnął przekształcić Paryż - mający jeszcze średniowieczny układ urbanistyczny - w nowoczesną metropolię. Inspiracją dla cesarza były dzielnice zachodniego Londynu, wzniesione po wielkim pożarze brytyjskiej stolicy w 1666 r. Napoleon miał możliwość poznać je, gdy przebywał w Anglii w czasie swojego wygnania z kraju w latach 1846-1848 ${ }^{13}$. Nowoczesna zabudowa Londynu stała się wzorem także dla Georges'a Eugène’a Haussmanna (1809-1891), któremu cesarz zlecił realizację tego ambitnego urbanistycznego przedsięwzięcia, mianując go prefektem departamentu Sekwany w czerwcu 1853 r.

Bezpośrednimi powodami zmian były problemy, jakie generowała sama struktura średniowiecznej zabudowy Paryża, charakteryzująca się krętymi, wąskimi korytarzami ulic, najczęściej pozbawionymi chodników. Labirynt ciemnych, zaniedbanych uliczek stanowił prawdziwą barierę, poważnie utrudniającą przemieszczanie się po mieście pieszych oraz coraz liczniejszych powozów ${ }^{14}$. Dodatkowych uciążliwości nastręczało słabe oświetlenie uliczek (lub wręcz jego brak) ${ }^{15}$. Nierówna, wyboista nawierzchnia pasaży, obniżająca się

8 J. Hillairet,op.cit., s. 150.

9 Zburzony w latach 1813-1814. J. Hill a ir e t, op. cit., s. 128; B. D u m o u ch el, L'église Saint-Denis-du-Pas, „Bulletin de la Société de l'histoire de Paris et de l'Île-de-France” 1992-1994, nr 119-122, s. 110-115.

10 J. Hillairet, op. cit., s. 150.

11 Wyburzenie w 1837 r. było związane w przebiciem rue d'Arcole. B. D u m o u ch el, L'église Saint-Pierreaux-Baufs, ,Bulletin de la Société historique de Paris et de l'Île-de-France” 1995-1997 [1999], nr 122-124, s. 31-35; E. Ren a d in, Paris-exposition ou guide à Paris en 1867. Histoire, monuments, musées, théâtres, curiosités vie pratique, Paris 1867, s. 20.

12 J. Hill a i re t, op. cit., s. 229-230; F. La za re, L. L a za re, Dictionnaire administratif et historique des rues de Paris et de ses monuments, Paris 1844, s. 221-222.

13 P.-A. Tou t ta in, Haussmann: artisan du Second Empire, créateur du Paris moderne, Paris 1971, s. 37-38.

14 Na temat złego stanu zabudowy Paryża przed zmianami urbanistycznymi wprowadzonymi w czasie Drugiego Cesarstwa zob.: P. de Moncan, Le Paris d'Haussmann, Paris 2009, s. 7-35; P.-A. Touttain, op. cit., s. 7; G. Un ge r, Histoire du Second Empire, Paris 2018, s. 195; D. H. Pin kn e y, Napoleon III and the rebuilding of Paris, Princeton 1958, s. 9, 14. Haussmann pisał m.in. o strukturze labiryntu i braku chodników. Mémoires du baron Haussmann, t. 3: Grands travaux de Paris, Paris 1893, s. 137-138, 145.

15 Przewodnik po Paryżu z roku 1851 podaje, że w całym mieście jedynie przez połowę roku zapalano ok. 12 tys. lamp gazowych i 1,6 tys. naftowych. W okresie wiosenno-letnim ich używanie było mocno 
w centralnej części wykorzystywanej jako kanał ściekowy pod gołym niebem, gromadziła nieczystości i odchody ludzkie i zwierzęce ${ }^{16}$. Miasto cuchnęło, a wąskie zaułki dodatkowo mocno ograniczały cyrkulację powietrza.

Taki stan rzeczy nie był obojętny dla zdrowia mieszkańców przeludnionego, ciasnego miasta, co poświadczała choćby wysoka umieralność dzieci. Przygnębiający obraz tamtych warunków pozostawił Victor Considerant w rozdziale swojej pracy poświęconym rozważaniom społecznym na temat architektury, wydając miażdżącą opinię: „Paryż jest ogromnym warsztatem gnicia, w którym nieszczęście, zaraza i choroba działają wspólnie, gdzie wcale nie przenikają ani powietrze, ani słońce. Paryż jest złym miejscem, gdzie rośliny więdną i giną, gdzie spośród siedmiu małych dzieci sześć umiera w ciągu roku” ${ }^{17}$. W tych urągających warunkach życia biedoty część medyków widziała przyczyny epidemii cholery z lat 1831-1832 i 1848-1849 ${ }^{18}$. Należy zwrócić uwagę także na przykre skutki społeczne tych nieludzkich realiów. Zaniedbane, biedne, przeludnione dzielnice, brudne i ciemne były miejscem powstawania patologii społecznych, nasilającej się przestępczości i prostytucji ${ }^{19}$.

Niechlubny prym w tym względzie wiodła wysepka na Sekwanie ${ }^{20}$. Już Napoleon Bonaparte miał bardzo negatywną opinię na temat starych zabudowań wyspy, określając je jako ruinę i dobre lokum dla szczurów ${ }^{21}$. Nie bez kozery pisarz Eugène Sue akcję swojej powieści Tajemnice Paryża, opisującej nędzne warunki życia najbiedniejszych, umieszcza właśnie na Île de la Cité22. Podobną opinię na temat tego miejsca miał George Eugène

ograniczone. Galignani’s New Paris Guide for 1851, Paris 1851, s. 39. O słabym oświetleniu pisał też Haussmann. Mémoires du baron Haussmann, t. 3, s. 152-154. Więcej na ten temat: S. D el at tr e, Les douze heures noires. La nuit à Paris au XIX'e siècle, Paris 2000, s. 81-85.

16 D. H. Pinkney, op. cit., s. 19-20.

17 „Paris, c'est un immense atelier de putréfaction, où la misère, la peste et les maladies travaillent de concert, où ne pénétrer guère l'air ni le soleil. Paris, c'est un mauvais lieu où les plantes s'étiolent et périssent, où sur sept petits enfans il en meurt six dans l'année", cyt. za: V. Co nside r a nt, Destinée sociale, Paris 1835, s. 462. Wszystkie cytaty w tłumaczeniu własnym.

18 Niehigieniczne warunki mieszkalne i ciasnota były wymieniane jako powody wybuchów epidemii cholery. P. de Moncan, Ch. Ma hou t, Le Paris du baron Haussmann. Paris sous le Second Empire. Centenaire du Baron Haussmann, 1891-1991. Les mémoires, Paris 1991, s. 37, 67-70. Szacuje się, że w latach 1831-1832 zarażonych było 39 tys. osób, spośród których zmarło 18,4 tys., natomiast w latach 1848-1849 było to 19 tys. mieszkańców stolicy. D. H. Pin kn e y, op. cit., s. 10, 23-24.

19 D. H. Pinkney, op. cit., s. 9-10.

20 O tym, że Cité było dzielnicą niebezpieczną, w której gnieździła się biedota oraz złodzieje i przestępcy, zob. m.in.: D. Ka lif a, Les lieux du crime. Topographie criminelle et imaginaire social à Paris au XIXe siècle, "Sociétés \& Représentations" 2004, t. 1, nr 17, s. 133, 137-139; N. P in o n, Alcool, drogues... et création artistique ? Essai de mise en perspective à travers la figure paradigmatique de Paul Verlaine, Louvain 2013, s. 43-44.

21 „Ce n'est plus qu'une vaste ruine, tout au plus bonne à loger les rats de l'ancienne Lutèce”, cyt. za: G. Va lance, Haussmann le grand, Paris 2000, s. 15. Podobne stanowisko prezentowano już w XVII w., por. B. Hryszko, op. cit., s. 139-140.

22 „[...] dans la Cité, dédale de rues obscures, étroites, tortueuses, qui s'étend depuis le Palais-de-Justice jusqu’à Notre-Dame”, cyt. za: E. Su e, Les mystères de Paris, Paris 1842, s. 5. 
Haussmann, który swoje stanowisko przedstawił w oświadczeniu wygłoszonym przed radą miejską Paryża. Konieczność wyburzenia m.in. Cité uzasadniał względami zarówno higienicznymi, jak i moralnymi: „Rozpruwając te stare bloki domów, rozwiązując uderzeniem kilofa tę plątaninę niezdrowych uliczek, pozwalając tam gwałtownie wedrzeć się powietrzu i słońcu, przynieśliśmy tam tylko zdrowie: umoralniliśmy te nędzne dzielnice, ponieważ wypędziliśmy złoczyńców, których światło dzienne przeraża i którzy nie znajdują już ukrycia w ogromnych przestrzeniach, gdzie wznosily się niegdyś ich popękane rudery"23. Przez pryzmat złego stanu technicznego oraz zaniedbania i brudu Haussmann postrzegał dzielnice ze średniowieczną zabudową jako obszary sprzyjające zbrodniczym postępkom ludzi z marginesu społecznego. Popularyzowane wówczas higieniczne podejście, promujące porządek i regulacyjne rozwiązania, rzutowało na negatywne podejście do średniowie$\mathrm{cza}^{24}$. Należy podkreślić, że Haussmann, pisząc w swoim pamiętniku o zabudowie wyspy, używa terminu o silnie pejoratywnym zabarwieniu - l'ignoble quartier, co możemy przetłumaczyć jako dzielnica „nikczemna” lub nawet „ohydna”25.

Średniowieczna zabudowa była traktowana nie tylko jako potencjalne siedlisko chorób lub przestępstw, uważano ją również za prawdopodobny ośrodek buntu ludu Paryża ${ }^{26}$. Po doświadczeniach powstań w lipcu 1830 r. oraz w lutym i czerwcu 1848 r. również ten aspekt brano pod uwagę w trakcie urbanistycznych przekształceń. Haussmann wprost pisał: „To było wypatroszenie starego Paryża, dzielnicy zamieszek, barykad, szeroką centralną drogą, przebijanie na wskroś tego labiryntu prawie niedostępnego" ${ }^{27}$.

Problemy, z którymi borykał się Paryż, leżały na sercu Napoleonowi III kierującemu się pragnieniem stworzenia w stolicy higienicznych warunków życia na miarę nowoczesnej metropolii ${ }^{28}$. Zarówno cesarz, jak i mianowany przez niego prefekt traktowali przemiany urbanistyczne w Paryżu jako misję mającą na celu uleczenie chorego miasta. Dobitnie poświadczają to przytoczone słowa prefekta: „przynieśliśmy tam tylko zdrowie”29. Proces

23 „En éventrant ces vieux pâtés de maisons, en démêlant à coups de pioche ces écheveaux de ruelles malsaines, en y faisant violemment entrer l'air et le soleil, on n'a pas seulement apporté la santé : on a moralisé ces quartiers misérables, car on a chassé les malfaiteurs que le grand jour épouvante et qui ne trouvent plus à se cacher dans les vastes espaces où se dressaient autrefois leurs taudis lézardés", cyt. za: Y. Le mo in e, Paris sur crime. L'Impossible histoire, Paris 1993, s. 131-132.

24 Więcej na temat higieny i wpływu teorii higienistycznych na urbanistykę XIX w.: G. Jo rl a nd, Une société à soigner. Hygiène et salubrité publiques en France au XIX' siècle, Paris 2010, passim.

25 Mémoires du baron Haussmann, t. 2: Prefecture de la Seine, Paris 1890, s. 487.

26 Na temat ruchów paryskich rewolucyjnych pierwszej połowy XIX w.: D. H. Pinkney, op. cit., s. 10; G. Unger, op. cit., s. 195.

27 „C'était l'éventrement du Vieux Paris, du quartier des émeutes, des barricades, par une large voie centrale, perçant de part en part ce dédale presque impraticable, accostée de communications transversales, dont la continuation devait compléter l'œuvre ainsi commencée". Mémoires du baron Haussmann, t. 3, s. 54.

28 P.de Moncan, Ch. Mahout, op. cit., s. 9-10.

29 Zob. przyp. 22. 
uzdrawiania obejmował udrożnienie skumulowanej, ciasnej i niewydolnej tkanki miejskiej poprzez wyciosanie w niej szerokich, prostych alei obsadzonych drzewami. Zabieg ten miał uregulować krążenie - tak ludzi, jak i towarów - po paryskich ulicach, swoistych tętnicach miasta; wzmocnić jego pluca poprzez doprowadzenie świeżego powietrza do niedotlenionych, starych dzielnic; usprawnić wydalanie odpadków dzięki systemowi kanalizacji ${ }^{30}$. Ten całościowo pomyślany proces leczenia miał tchnąć w stolicę cesarstwa nowe życie - komunikacyjne, społeczne, gospodarcze. Do dokumentowania przebiegu „leczenia” Haussmann zatrudnił fotografów, m.in. Charles’a Marville’a, który wykonywał zdjęcia paryskich dzielnic przed i w trakcie wyburzeń oraz już po wprowadzeniu zmian ${ }^{31}$.

\section{Przebieg prac na wyspie}

W latach pięćdziesiątych i sześćdziesiątych XIX w. usunięto średniowieczną zabudowę wyspy wraz z kolejnymi dwoma zdesakralizowanymi kościołami: św. Mariny i św. Bartłomieja (funkcjonującym wówczas jako sala balowa Le Prado), a następnie na ich miejscu rozplanowano gmachy użyteczności publicznej.

Zburzony w 1858 r. kościół św. Bartłomieja ${ }^{32}$ ustąpił pola nowej siedzibie Trybunału Handlu (Tribunal de commerce), która miała zastąpić wcześniejszą, zbyt ciasną w Palais de la Bourse ${ }^{33}$. Budowlę wzniesiono w latach 1860-1865 według planów architekta Antoine'a-Nicolasa Bailly'ego ${ }^{34}$. Haussmann wzmiankował w swoich wspomnieniach, iż również on miał duży wpływ na proces wznoszenia gmachu, ponieważ polecił cesarzowi osobę architekta oraz wybrał dla nowego budynku atrakcyjną lokalizację, tworzącą oś widokową rozciągającą się z wytyczonego w 1854 r. Boulevard du Centre (przemianowanego rok później na Boulevard de Sébastopol). Pośredniczył też w przekazaniu architektowi polecenia Napoleona III, aby wzorował się na ratuszu w Brescii (Palazzo della Loggia) ${ }^{35}$. Wzór formalny wskazany przez cesarza dowodził jego bezpośredniego zaangażowania w proces wznoszenia nowych reprezentacyjnych gmachów urzędów - w tym przypadku

30 G. Unger, op. cit., s. 196.

31 Tej cennej dokumentacji fotograficznej została poświęcona wystawa w 1981 r.: Charles Marville, photographs of Paris at the time of the Second Empire on loan from the Musée Carnavalet, Paris, French Institutel Alliance Française, New York, May 13-June 26, 1981, Yale University Art Gallery, New Haven, Connecticut, July 1-August 16, 1981, edited and designed by J. Chambord, Wellesley College Museum, Wellesley, Massachusetts, September 4-October 18, 1981, New York 1981.

32 J. Hillairet, op. cit., s. 142, 150.

33 Mémoires du baron Haussmann, t. 2, s. 486-487.

34 Wcześniej stały tam kościoły Saint-Pierre-des-Arcis i Saint-Barthélemy: J. Hillairet, op. cit., s. 228; A. Ayers, The Architecture of Paris. An Architectural Guide, Paris 2004, s. 77.

35 Mémoires du baron Haussmann, t. 2, s. 488. 
dla Trybunału Handlu, który był siedzibą m.in. Tribunal de Première Instance i Conseils de Prud'hommes ${ }^{36}$.

Z kolei na terenie zburzonych średniowiecznych uliczek, wśród których do 1722 r. stał kościół św. Eligiusza z klasztorem św. Marcjala ${ }^{37}$, w latach 1863-1867 wzniesiono budynek koszar zaprojektowany przez Pierre'a-Victora Calliata ${ }^{38}$. Z inicjatywy Haussmanna utworzono również szeroki dziedziniec przed Notre Dame ${ }^{39}$, usuwając m.in. pozostałości po dawnym Hôtel-Dieu położonym wzdłuż Sekwany, którego spora część spłonęła w $1772 \mathrm{r}^{40}$ Nowy gmach Hôtel-Dieu wzniesiono w latach 1866-1876 w północnej części wyspy według planów Emile’a Jacques’a Gilberta i Arthura-Stanislasa Dieta ${ }^{41}$. Instytucja ta powstała na miejscu zajmowanym niegdyś przez kościoły: św. Marii Magdaleny, Saint-Denis-de-laChartre, św. Symforiusza, św. Landeryka i Saint-Pierre-aux-Bœufs. Większość rozebrano wcześniej, jedynie kościół św. Mariny wyburzono w latach 1865-1866, czyli bezpośrednio przed wzniesieniem nowego szpitala ${ }^{42}$.

W tym samym czasie prace budowlane trwały również w Pałacu Sprawiedliwości (Palais de Justice), jednak ich efekty uległy zniszczeniu podczas pożaru w czasie Komuny Paryskiej (w nocy 24 maja 1871 r.). Kolejny raz pałac został przebudowany i powiększony przez Josepha-Louisa Duca i Honoré Daumeta ${ }^{43}$ w latach 1875-1883. Po rekonstrukcji gmach przypadł centralnym instytucjom sądowym państwa, m.in. Cour de cassation, Cour d'appel de Paris i Cour d'Assises ${ }^{44}$.

\section{Skutki przebudowy}

W wyniku przebudowy rozwiązano zasadniczy problem natury sanitarnej, który był ewokowany przez stare, niedoświetlone i brudne ulice oraz brak kanalizacji. Ponadto nowe,

36 Ibidem, s. 486-487.

37 J. Hillairet, op. cit., s. 135.

38 W 1929 r. budynek przejęła prefektura policji (Préfecture de Police), która wcześniej mieściła się w dawnym Hôtel de Lamoignon w pobliżu Sainte-Chapelle. Mémoires du baron Haussmann, t. 2, s. 485.

39 A. Richard-Bazire, Le parvis de Notre-Dame, [w:] Autour de Notre-Dame, red. A. Erlande-Bra ndenburg [et al.], Paris 2003, s. 240-242.

40 Mimo zniszczeń szpital funkcjonował aż do jego wyburzenia w 1866 r. Ideę odbudowania szpitala w tym samym miejscu odrzucono. Mémoires du baron Haussmann, t. 2, s. 488

${ }^{41}$ J. Hill a i r et, op. cit., s. 231-232; Ch. Co u ry, L'Hôtel-Dieu de Paris: treize siècles de soins, d'enseignement et de recherche, Paris 1969, s. 25.

42 E. Ren audin, op. cit., s. 20; J. Hilla iret, op. cit., s. 67.

43 Plans du Palais de justice de Paris, par Honoré Daumet, architecte du Palais, Paris 1895, [on-line:] https:// criminocorpus.org/fr/bibliotheque/doc/1962/ - 20 XI 2018; J. Hilla ir et, op. cit., s. 205-206.

44 Mémoires du baron Haussmann, t. 2, s. 486. 
proste i szerokie bulwary rozdzielające monumentalne gmachy ułatwiały w razie zamieszek sprawną interwencję wojskową i szybką likwidację rozruchów ${ }^{45}$. Ten militarno-polityczny aspekt nowej urbanistyki, wynikający z obawy przed obaleniem imperium, został wzmocniony wzniesieniem na wyspie koszar. Bliskość siedziby wojska zabezpieczała znajdujące się w sąsiedztwie ważne dla funkcjonowania państwa urzędy: Trybunał Handlu, Pałac Sprawiedliwości, Hôtel-Dieu. Instytucje te reprezentowały sądownictwo i świeckie szpitalnictwo, które zastąpiło wcześniejsze szpitalnictwo kościelne. Natomiast dziedziniec przed Notre Dame pozwalał wyeksponować walory estetyczne katedry - centrum władzy kościelnej oraz monumentalnego pomnika przeszłości.

Umieszczenie centrum administracyjnego w sercu stolicy, a szczególnie skoncentrowanie gmachów władzy sądowniczej na wyspie, podkreślało znaczenie instytucji państwowych, zarazem budowało w ten sposób prestiż cesarstwa. Ponieważ wiele dokumentów na temat ówczesnej przebudowy Paryża spłonęło podczas Komuny Paryskiej w $1871 \mathrm{r}^{46}$, trudno zweryfikować dokładne proporcje wpływu Napoleona III i Haussmanna na wygląd metropolii, należy jednak przypuszczać, że osobiste zaangażowanie władcy w projekt było dużo większe niż to przedstawiał Haussmann w swych wspomnieniach spisywanych dopiero w okresie Trzeciej Republiki, a zatem w czasie, gdy był już niezależny od dawnego mocodawcy i mógł sobie pozwolić na nadmierne zaakcentowanie własnej roli w procesie modernizacji stolicy ${ }^{47}$. W pamiętnikach Haussmann przekazał potomnym swoją wersję na tyle skutecznie, iż tę fazę przemian w paryskiej urbanistyce powszechnie określa się jako haussmannizację. Tymczasem funkcja prefekta polegała przede wszystkim na realizacji planów zarysowanych wcześniej przez samego Napoleona III oraz przez powołaną na jego polecenie komisję (Commission des embellissements de Paris) ${ }^{48}$. Po latach niesłusznie umniejszano rolę władcy, podczas gdy nawet z pamiętnika Haussmanna wyzierają fakty świadczące o osobistym zaangażowaniu cesarza w modernizację stolicy, takie jak np. wskazanie wzoru dla siedziby Trybunału Handlu. Należy również pamiętać, iż to właśnie znany z wrażliwości społecznej Napoleon III był promotorem budowania mieszkań socjalnych dla robotników, a zainspirowany przejrzystym układem Londynu stał się spiritus movens modernizacji stolicy swojego imperium. Na osobiste zaangażowanie władcy w planowanie przyszłego kształtu miasta wskazywała m.in. legenda głosząca, że „Napoleon III przybył w 1848 r. na paryski dworzec Gare du Nord z mapą pod pachą, zawierającą przyszłe nowe

45 Na temat antyrewolucyjnych założeń przebudowy: A. Callet, Paris monumental sous la République de 1848 et sous Napoléon III, [w:] Paris de 1800 à 1900 d'après les estampes et les mémoires du temps, red. Ch. Si mo nd, t. 2: 1830-1870. La Monarchie de Juillet. La Seconde République. Le Second Empire, Paris 1900, s. 726; J. des Cars, P. Pin on, Paris-Haussmann. «Lepari de Haussmann», Paris 1991, s. 74-76.

46 C. Jon es, Paris: Biography of a City, New York 2005, s. 299.

47 Mémoires du baron Haussmann, t. 2-3, passim.

48 Por. Commission des embellissements de Paris, rapport à l'empereur Napoléon III, rédigé par le comte Henri Siméon (décembre 1853), oprac. P. C a ss ell e, Paris 2000, passim; C. Jo n es, op. cit., s. 304. 
bulwary nakreślone kolorowymi kredkami”99. Co więcej, już w 1842 r., gdy Napoleon był uwięziony w zamku Ham, napisał do badacza historii starożytnej Amédée’a Thierry’ego: „Będę Augustem, ponieważ Oktawian, jak twierdzą jego panegiryści, uczynił Rzym miastem z marmuru"so. To śmiałe wyznanie przyszłego cesarza wyrażało jego pogłębione zainteresowanie urbanistyką oraz wielkie ambicje w zakresie zmian Paryża, które to miasto pragnął przeobrazić w drugi Rzym, wzorując się na rzymskim imperatorze Oktawianie Auguście. Przekazy te ukazują osobiste zaangażowanie władcy w nadanie stolicy nowego kształtu oraz dowodzą, jak ważną funkcję miała do spełnienia nowoczesna urbanistyka Paryża w propagandowym przedstawianiu Drugiego Cesarstwa.

Okres panowania Napoleona III pozostawił trwałe piętno na zabudowie Paryża odtąd nowoczesnej, europejskiej metropolii. Jej urbanistyczna przebudowa jest w zasadniczym stopniu realizacją osobistej, jednolitej i holistycznej wizji cesarza, w której szerokie korytarze arterii komunikacyjnych wskazują na monumentalne gmachy, np. gmach opery został wyeksponowany z odległej perspektywy Avenue de l'Opéra, z kolei siedziba Trybunału Handlu na Île de la Cité zamyka widok z Boulevard de Sébastopol. W tej wizji wyspa odzyskała swoje centralne miejsce jako obszar przeznaczony dla reprezentacyjnych, nowoczesnych i monumentalnych gmachów użyteczności publicznej, przedzielonych prostymi, szerokimi ulicami (il. 2). Île de la Cité, będąca kwintesencją ówczesnej estetyki, stała się zarazem symptomatyczną wyrazicielką idei politycznych i państwowych. Rozmach, monumentalizm i nowoczesność Paryża miały głosić potęgę Drugiego Cesarstwa. Potęga ta wyrażała się zaś nie tylko w uzyskanym efekcie urbanistycznym, ale również w sposobie jego osiągnięcia. Warunkiem skuteczności było autorytarne, bezkompromisowe działanie polegające na wyburzaniu dużych obszarów miasta, nawet całych dzielnic, co ułatwiały nowe przepisy dotyczące wywłaszczeńs ${ }^{1}$. Dzięki temu osiągnięte efekty były śmiałe i dobitnie świadczyły o sile Drugiego Cesarstwa. Zastosowane w stolicy nowe zdobycze cywilizacyjne z dumą prezentowano międzynarodowej społeczności na wystawach światowych w Paryżu w latach 1855 i $1867^{52}$.

49 Cyt. za: C. Jones, op. cit., s. 299.

50 Napoleon III napisał do Amédée’a Thierry'ego: „«Je serai Auguste», parce qu’Octave, disent ses panégyristes, «fit de Rome une ville de marbre»”, cyt. za: A. des Cilleuls, Histoire de l'administration parisienne au XIXe siècle, t. 2, Paris 1900, s. 208. Trochę inaczej słowa przyszłego cesarza przytacza Gérard Unger: „Je veux être un nouvel Auguste, parce qu'Auguste a fait de Rome une ville de marbre”, cyt. za: G. Unger, op. cit., s. 196.

51 G. Unger, op. cit., s. 196. Na temat działań poprzedników Haussmanna, którzy stosowali bardziej polowiczne, a przez to mniej skuteczne metody: J. DeJean, How Paris Became Paris. The Invention of the Modern City, New York 2014, s. 96-120; La modernité avant Haussmann. Formes de l'espace urbain à Paris, 1801-1853, oprac. K. B ow i e, Paris 2001, passim.

52 Za przykład może posłużyć zaprezentowanie na ekspozycji w 1867 r. projektów mieszkań robotniczych wzniesionych na polecenie Napoleona III w Paryżu przy Avenue Daumesnil: M.-J. D u m o n t, Le logement social à Paris, 1850-1930. Les habitations à bon marché, Liège 1991, s. 14-16. 


\section{Wnioski}

Zmiany urbanistyczne w Paryżu w okresie Drugiego Cesarstwa były postrzegane przez współczesnych jako podwójnie korzystne. Z jednej strony likwidowały problem niehigieniczności starych, brudnych i przeludnionych dzielnic, z drugiej zaś zapewniały kontrolę militarną w razie oddolnych ruchów rewolucyjnych. Dodatkowo realizowały potrzebę osadzenia w centralnym, odtąd prestiżowym miejscu, najważniejszych urzędów państwowych, co dodawało cesarstwu autorytetu i powagi. W ten sposób Paryż, a szczególnie centrum instytucjonalne na wyspie, spełniało XIX-wieczne wymogi higieniczne, utylitarne, militarne i reprezentacyjne.

Pozytywna ocena działań urbanistycznych za panowania Napoleona III szybko uzyskała przeciwwagę w postaci bardzo ostrej krytyki. Za przykład mogą posłużyć opinie Victora Hugo, który bezpardonowo atakował osoby odpowiedzialne za niszczenie starego Paryża ${ }^{53}$. Miażdżąca krytyka spadła na Haussmanna przede wszystkim za unicestwienie średniowiecznej zabudowy Île de la Cité, co pociągnęło za sobą wyludnienie dzielnicy ${ }^{54}$. Również współczesny żal po utracie historycznej struktury wyspy jest w pełni zrozumiały - naszą nostalgię budzi usunięcie średniowiecznej tkanki miejskiej, która obecnie byłaby silnym magnesem przyciągającym turystów z całego świata. Trzeba jednak pamiętać, że dzisiejsza optyka jest odmienna od spojrzenia na problem w pierwszej połowie XIX w. Wówczas tak wyglądał nie tylko cały Paryż, ale i zdecydowana większość starych europejskich miast, przez co deprecjonowano historyczną wartość zaniedbanej średniowiecznej zabudowy. Myślano o niej nie jako o zabytku czy świadku przeszłości, a raczej jak o poważnym zagrożeniu sanitarno-epidemiologicznym, upatrywano w niej także źródeł moralnego i politycznego niebezpieczeństwa dla Drugiego Cesarstwa. W tym kontekście pozostawienie na wyspie skansenu dawnego budownictwa, a de facto ruin, było nierealne. Nie zmienia to faktu, iż bezkompromisowe „oczyszczanie” miasta na Cité, właściwie wydrążenie wyspy z jej średniowiecznego miąższu, do dziś budzi u wielu smutek. Pozostając w ulubionej XIX-wiecznej metaforyce medycznej, trzeba stwierdzić, że jeśli modernizacja Paryża była kuracją, to w odniesieniu do Cité była amputacją i zastąpieniem usuniętego organu (tkanki sakralno-mieszkalnej) zupełnie innym, nowoczesnym elementem (gmachami urzędowymi).

53 W niemal wszystkich utworach słynnego pisarza, wygnanego z Francji w 1852 r., przewija się bardziej lub mniej bezpośrednia krytyka działań Haussmanna. Za przykład mogą posłużyć utwory w zbiorze: V. Hug o, Les Années funèstes, 1852-1870. Derniere gerbe, Paris 1941, s. 102, 150.

54 Podejście to wyraźnie przeważa w XX-wiecznych publikacjach, np.: H. Ma le t, Le baron Haussmann et la rénovation de Paris, przedmowa A. D a n se t te, Paris 1973, s. 298-299; D. P. Jo r d a n, Transforming Paris. The Life and Labors of Baron Haussmann, Chicago 1995, s. 198-200; W. We eks, The Man Who Made Paris. Paris. The Illustrated Biography of George-Eugene Haussmann, London 1999, s. 124; N. Ch a u d u n, Haussmann au crible, Paris 2000, s. 170. 
Swoista rewolucja urbanistyczna na Cité wynikała z centralnego usytuowania wyspy, której lokalizacja okazała się najbardziej odpowiednia dla monumentalnych gmachów urzędowych reprezentujących państwo. Problemem pozostawała stosunkowo niewielka przestrzeń wyspy - ponieważ rozłożyste obiekty rządowe nie mogły być upchnięte między dawną zabudowę, jedynym wyjściem okazało się zburzenie niemal całej dzielnicy. Atrakcyjna, centralna lokalizacja stała się przekleństwem dla średniowiecznej tkanki urbanistycznej. Ostatecznie zaś rewolucja, jaka dokonała się na Cité, stała się wyrazistym symbolem mówiącym o autorytarnej sile Drugiego Cesarstwa.

\section{BIBLIOGRAFIA}

Ayers A., The Architecture of Paris. An Architectural Guide, Paris 2004.

Callet A., Paris monumental sous la République de 1848 et sous Napoléon III, [w:] Paris de 1800 à 1900 d'après les estampes et les mémoires du temps, red. Ch. Simond, t. 2 : 1830-1870. La Monarchie de Juillet. La Seconde République. Le Second Empire, Paris 1900, s. 725-728.

Carbonnier Y., Lîlle de la Cité au XVIIIe siècle. Rénovation urbaine et adaptations habiles, [w:] Histoire de Paris. De l'âge classique à la modernité (XVIIe-XVIIIe siècle), red. Th. Belleguic, L. Turcot, Paris, 2013, s. 359-381.

Charles Marville, photographs of Paris at the time of the Second Empire on loan from the Musée Carnavalet, Paris, French Institute/Alliance Française, New York, May 13-June 26, 1981, Yale University Art Gallery, New Haven, Connecticut, July 1-August 16, 1981, edited and designed by J. Chambord, Wellesley College Museum, Wellesley, Massachusetts, September 4-October 18, 1981, New York 1981.

Chaudun N., Haussmann au crible, Paris 2000.

Commission des embellissements de Paris, rapport à l'empereur Napoléon III, rédigépar le comte Henri Siméon (décembre 1853), oprac. P. Casselle, Paris 2000.

Considerant V., Destinée sociale, Paris 1835.

Coury Ch., L'Hôtel-Dieu de Paris: treize siècles de soins, d'enseignement et de recherche, Paris 1969.

DeJean J., How Paris Became Paris. The Invention of the Modern City, New York 2014.

Delattre S., Les douze heures noires. La nuit à Paris au XIX'e siècle, Paris 2000.

Des Cars J., Pinon P., Paris-Haussmann. «Le pari de Haussmann», Paris 1991.

Des Cilleuls A., Histoire de l'administration parisienne au XIX ${ }^{e}$ siècle, Paris 1900.

Dumont M.-J., Le logement social à Paris, 1850-1930. Les habitations à bon marché, Liège 1991.

Dumouchel B., L'église Saint-Denis-du-Pas, „Bulletin de la Société de l'histoire de Paris et de l'île-de -France" 1992-1994, nr 119-122, s. 95-115.

Dumouchel B., L'église Sainte-Marie-Madeleine ou La Madeleine-en-la-Cité (1182-1794), „Bulletin de la Société de l'histoire de Paris et de l'Île-de-France" 1988 [1989], nr 115, s. 21-46.

Dumouchel B., L'église Saint-Germain-le-Vieux, „Bulletin de la Société de l'histoire de Paris et de l'île-de-France" 1990 [1992], nr 117, s. 19-44.

Dumouchel B., L'église Saint-Pierre-aux-Baufs, „Bulletin de la Société historique de Paris et de l'Île-de -France" 1995-1997 [1999], nr 122-124, s. 31-35.

Fosseyeux M., L'Hôtel-Dieu de Paris au XVII'et XVIII' siècle, Paris 1912.

Galignani's New Paris Guide for 1851, Paris 1851. 
Hall T., Planning Europe's Capital Cities. Aspects of Nineteenth-Century Urban Development, London 1997.

Hillairet J., L'île de la Cité, Paris 1969.

Hryszko B., Od sacrum do profanum. Desakralizacja Île de la Cité w Paryżu w XVIII i XIX wieku, [w:] Sacrum w mieście: wymiar kulturowy, religijny i spoteczny, t. 2: Epoka nowożytna i czasy wspótczesne, red. D. Quirini-Popławska, Ł. Burkiewicz, Kraków 2016, s. 131-155.

Hugo V., Les Années funèstes, 1852-1870. Derniere gerbe, Paris 1941.

Jones C., Paris: Biography of a City, New York 2005.

Jordan D. P., Transforming Paris. The Life and Labors of Baron Haussmann, Chicago 1995.

Jorland G., Une société à soigner. Hygiène et salubrité publiques en France au XIX'e siècle, Paris 2010.

Kalifa D., Les lieux du crime. Topographie criminelle et imaginaire social à Paris au XIXe siècle, „Sociétés \& Représentations" 2004, t. 1, nr 17, s. 131-150, https://doi.org/10.3917/sr.017.0131.

La modernité avant Haussmann. Formes de l'espace urbain à Paris, 1801-1853, oprac. K. Bowie, Paris 2001.

Lazare F., Lazare L., Dictionnaire administratif et historique des rues de Paris et de ses monuments, Paris 1844.

Lemoine Y., Paris sur crime. L'Impossible histoire, Paris 1993.

Malet H., Le baron Haussmann et la rénovation de Paris, przedmowa A. Dansette, Paris 1973.

Mémoires du baron Haussmann, t. 2: Préfecture de la Seine, Paris 1890.

Mémoires du baron Haussmann, t. 3: Grands travaux de Paris, Paris 1893.

Moncan P. de, Mahout Ch., Le Paris du baron Haussmann. Paris sous le Second Empire. Centenaire du Baron Haussmann, 1891-1991. Les mémoires, Paris 1991.

Moncan P. de, Le Paris d'Haussmann, Paris 2009.

Pinkney D. H., Napoleon III and the rebuilding of Paris, Princeton 1958.

Pinon N., Alcool, drogues... et création artistique? Essai de mise en perspective à travers la figure paradigmatique de Paul Verlaine, Louvain 2013.

Plans du Palais de justice de Paris, par Honoré Daumet, architecte du Palais, Paris 1895, [on-line:] https://criminocorpus.org/fr/bibliotheque/doc/1962/ - 20 XI 2018.

Renaudin E., Paris-exposition ou guide à Paris en 1867. Histoire, monuments, musées, théâtres, curiosités vie pratique, Paris 1867.

Richard-Bazire A., Le parvis de Notre-Dame, [w:] Autour de Notre-Dame, red. A. Erlande-Brandenburg [et al.], Paris 2003, s. 240-242.

Sue E., Les mystères de Paris, Paris 1842.

Touttain P.-A., Haussmann: artisan du Second Empire, créateur du Paris moderne, Paris 1971.

Unger G., Histoire du Second Empire, Paris 2018.

Valance G., Haussmann le grand, Paris 2000.

Weeks W., The Man Who Made Paris. Paris. The Illustrated Biography of George-Eugene Haussmann, London 1999. 


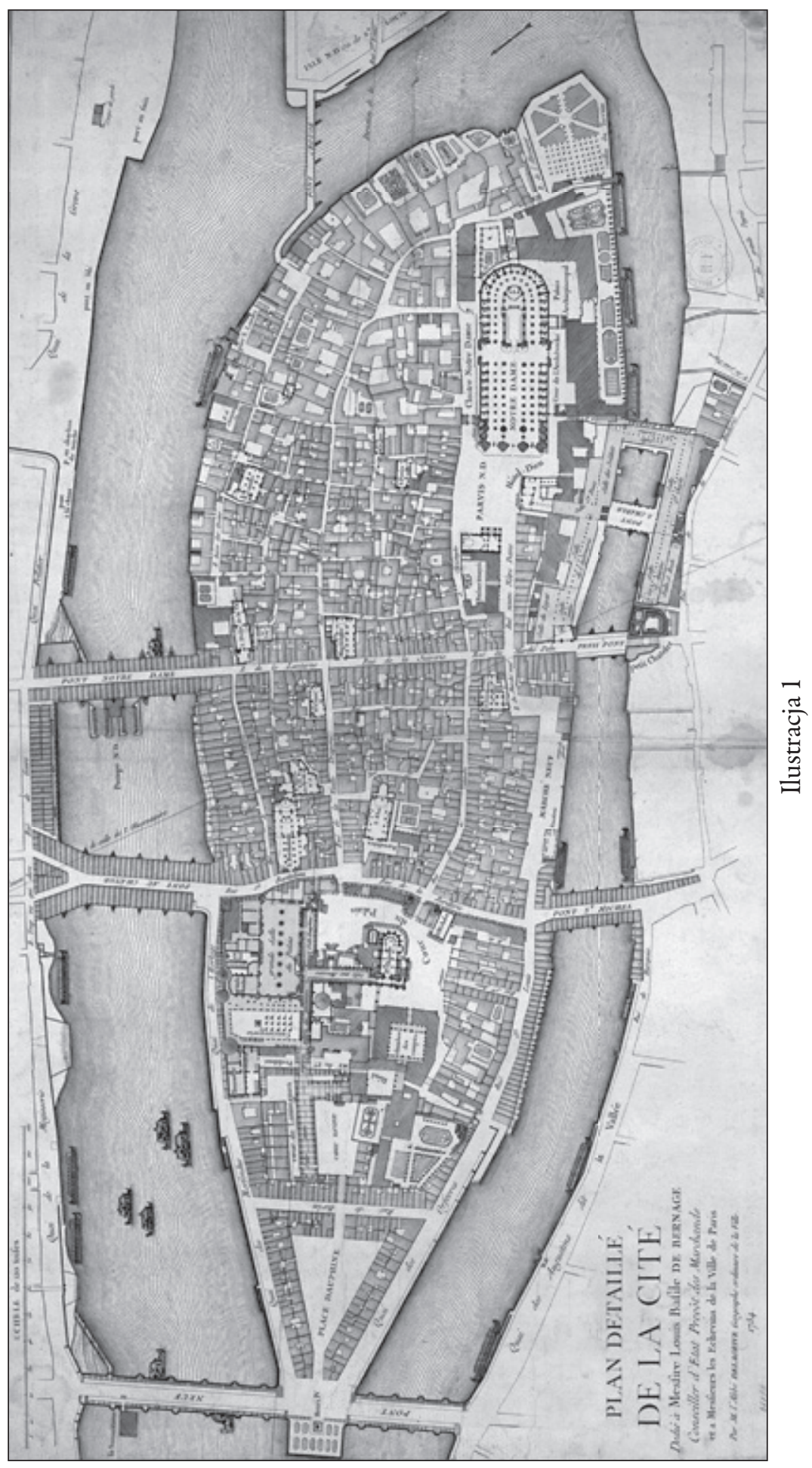




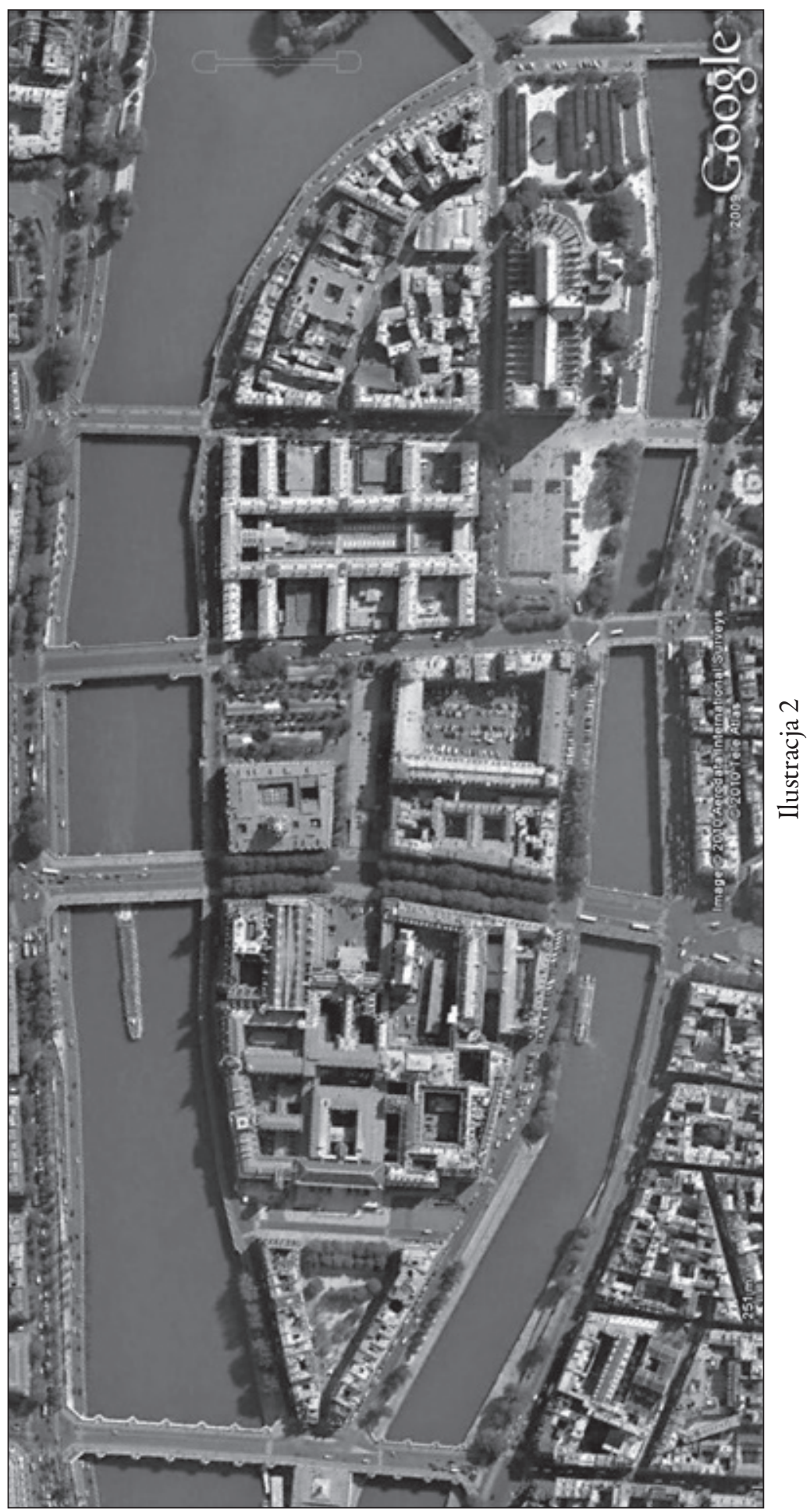

